\title{
INVESTIGATION OF LEAD AND CADMIUM CONTAMINATION IN MINE SOIL AND METAL ACCUMULATION IN SELECTED PLANTS GROWING IN A GOLD MINING AREA
}

\author{
LU, N. ${ }^{1,2,3,4,5}$ - LI, G. ${ }^{1,2,3,4,5}$ - HAN, J. C. ${ }^{1,2,3,4,3^{*}}-$ WANG, H. Y. $.^{1,2,3,4,5}-$ YANG, W. $.^{1,2,3,4,5}-$ SUN, Y. Y..$^{1,2,3,4,5}$ \\ ${ }^{I}$ Shaanxi Provincial Land Engineering Construction Group Co., Ltd. \\ Xi'an 710075, China \\ ${ }^{2}$ Shaanxi Key Laboratory of Land Consolidation, Xi'an 710075, China \\ ${ }^{3}$ Institute of Land Engineering and Technology, Shaanxi Provincial Land Engineering \\ Construction Group Co., Ltd., Xi'an 710075, China \\ ${ }^{4}$ Key Laboratory of Degraded and Unused Land Consolidation Engineering, the Ministry of \\ Natural Resources, Xi'an 710075, China \\ ${ }^{5}$ Shaanxi Provincial Land Consolidation Engineering Technology Research Center \\ Xi'an 710075, China \\ *Corresponding author \\ e-mail: hanjc_sxdj@126.com; phone:(029)86625019
}

(Received $1^{\text {st }}$ Mar 2019; accepted $21^{\text {st }}$ May 2019)

\begin{abstract}
To fully understand and evaluate the impact of lead and cadmium on the surrounding soil pollution in tailings from gold ore dressings, 36 soil samples were collected at different depths near an abandoned concentrating mill in a gold mining area. By examining the lead and cadmium contents in the soil samples, the degree of lead and cadmium pollution over the soil profile was analyzed at different sampling points. Meanwhile, 12 typical plant samples, including Bulrush (Phragmites communis (Cav.) Trin. ex Steud.), Capillary Wormwood (Artemisia capillaris), Heteropappusaltaicus (Artemisia gmelinii) and Stipa (Stipa capillata Linn.) were collected at the soil sampling point. The lead and cadmium contents were determined in the aboveground and belowground organs, and the enrichment and transfer coefficients of each plant sample were calculated. The results showed that both lead and cadmium were moderately polluted within $0-10 \mathrm{~m}$ of the tailing dump. The lead and cadmium contents over the depth profile of $0-30 \mathrm{~cm}$ were higher at depths of $0-10 \mathrm{~cm}$ and $20-30 \mathrm{~cm}$ than at $10-20 \mathrm{~cm}$. Heteropappusaltaicus showed more significant enrichment and transfer effects and large coverage and can thus be used as the phytoremediation material for the remediation of $\mathrm{Cd}$ - and $\mathrm{Pb}$-polluted soil around tailing slag.
\end{abstract}

Keywords: tailing slag, lead and cadmium pollution, phytoremediation, enrichment, migration

\section{Introduction}

Mine tailings are by-products of mineral processing, usually, they are rich in significant quantities of heavy metals (Wang et al., 2017a). In modern society, heavy metal pollution in agricultural soil from mining has been becoming serious and widespread (Marrugo-Negrete et al., 2017; Yang et al., 2018). The National Communique on Soil Pollution Survey Bulletin issued in April 2014 showed that the soil environment in China was negative, and the environmental problems of industrial and mining wasteland were in evidence. Inorganics were the main type of pollution. Inorganic cadmium $(\mathrm{Cd})$ and lead $(\mathrm{Pb})$ pollutants were found in excesses of $7.0 \%$ and $1.5 \%$, respectively in China (Luo and Tu, 2018). In $16.1 \%$ farmland soils, heavy metals 
have exceeded the environmental quality standard (Mahar et al., 2016). The processes of industrial production, mining development, sewage irrigation and rock weathering are the main ways heavy metals enter the soil ecosystem (Pascaud et al., 2015; Sankhla et al., 2016; Ashraf et al., 2017; Jing et al., 2018). Pb and Cd also cause damage to human health. Heavy metals are difficult to decompose through biological cycling and energy exchange and are difficult to remove, resulting in heavy-metal-contaminated soils (Arora et al., 2015; Mahar et al., 2016; Wang et al., 2017b). Shaanxi province is rich in mineral resources. The development of mineral resources has brought great economic benefits as well as serious environmental problems. As the deposits are mostly related to or associated with metals, one can assume the metal smelting process leaches heavy metals. In addition, a single mining mode is mostly used in China at present, which coupled with the low recovery rate and the comprehensive utilization rate, is not only a great waste of resources but has also led to serious ecological destruction and environmental pollution.

Phytoremediation technology can be used for in situ remediation (Filippis, 2015) and is a clean, green and environmentally friendly technology for the treatment of heavymetal-polluted soil. Compared with other technologies, phytoremediation does not cause secondary environmental problems but instead increases the soil organic matter content (Sarwar et al., 2017; Fiorentino et al., 2017; Ashraf et al., 2017), and the repair period is short and adaptable, making phytoremediation suitable for repairing large areas (Taj and Rajkumar, 2016; Kim et al., 2019).

Although some results in the scientific literature have shown that some plants have cumulative effects on $\mathrm{Pb}$ and $\mathrm{Cd}$, there are large differences in growth status and enrichment characteristics under different geographical climates. Through the determination of heavy metals in $\mathrm{Pb}$ - and $\mathrm{Cd}$-contaminated soils and surrounding plants in gold mining areas, several plants with tolerance to heavy metal pollution or the ability to enrich heavy metals were screened to provide a scientific reference for applying phytoremediation technology to heavy metal pollution in mining areas.

\section{Materials and methods}

\section{Description of the research area}

The research area is located in Yao Shang Village, Taiyao Town, Tongguan County.

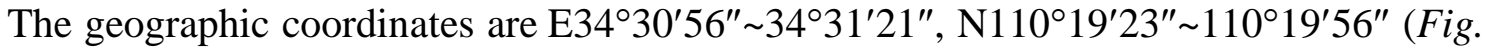
1). The small gold mining area in the Qinling Mountains is the second largest goldproducing area in China. It mainly exploits quartz-veined gold deposits and has a warm, temperate continental monsoon climate with four seasons, with an annual average temperature of $13^{\circ} \mathrm{C}$, sunshine duration of 2269 hours and frost-free period of 190 days. The ore dressing tailings were stacked at random along the river and bank slope, causing soil and water pollution.

\section{Sample collection}

\section{Collection of plant samples}

Sampling was carried out on August 23th and 24th, 2016. A total of 4 sampling sites of $10 \mathrm{~m}, 30 \mathrm{~m}$ and $50 \mathrm{~m}$ to the north of the tailing pile and slag pile were set up, and square sample boxes were used to investigate plants near the sampling points and collect a number of typical plants along with the roots, such as Bulrush, Capillary 
Wormwood, Heteropappusaltaicus and Stipa. For each plant sample, 3 to 5 plants with similar growth periods that were well developed were selected from the area and packed in kraft paper bags for analysis.

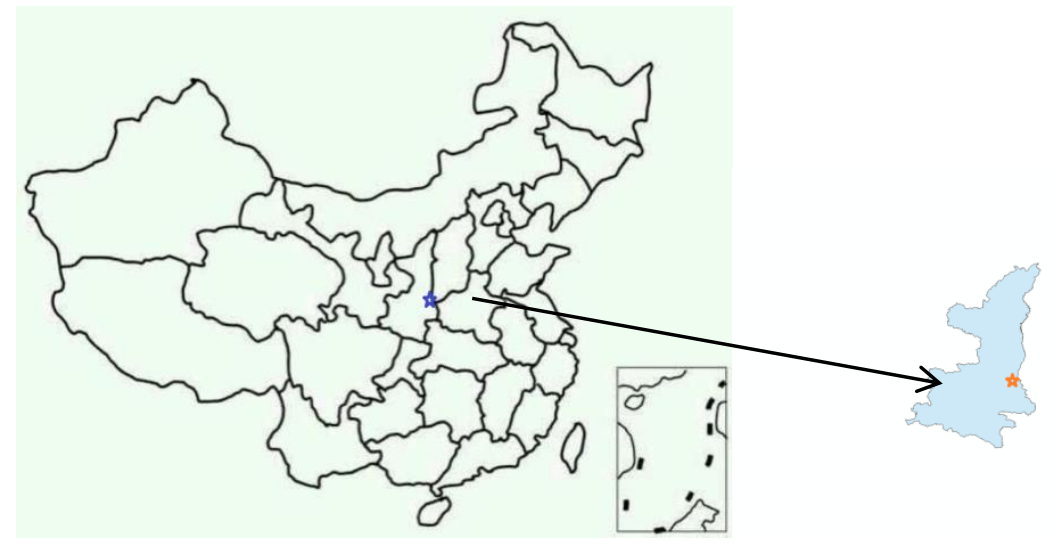

Figure 1. Description of the research area

\section{Collection of soil samples}

The tailings slag stacked in low-lying areas not far from the road in the open air. The top of the tailings slag was basically equal to the the height of the roadbed. The tailings slag thickness is about $30-40 \mathrm{~cm}$, and it seems to be landfilling construction waste down there. Soil samples were collected by the plum sampling method along the main wind direction. The plum sampling method picks five samples based on the shape of a plum along with the center point at the diagonal intersection. At each sampling point, soil samples of 0-10 cm, 10-20 cm, 20-30 cm were collected (three times) and the remaining sample was approximately $1 \mathrm{~kg}$ using the quartile method. Soil samples were sealed in a plastic bag to avoid sample contamination. The sampling location and the surrounding environment were recorded accurately, and a total of 36 tailings (N34 $30^{\prime} 58^{\prime \prime}$ E110 $\left.19^{\prime} 45^{\prime \prime}\right)$ and 36 soil samples were collected.

\section{Sample processing and determination}

\section{Treatment and determination of plant samples}

The plant samples were separated into aboveground and underground organs, which were then treated separately. The samples were cleaned and washed with deionized water and placed in an oven at $105^{\circ} \mathrm{C}$ for approximately $30 \mathrm{~min}$. Then, the temperature was adjusted to $75^{\circ} \mathrm{C}$ until reaching a constant plant weight, which was taken as the dry weight (g) (Environment Pollution Analysis Method, 1987). The samples were milled by agate mortar and then sieved with a $0.25 \mathrm{~mm}$ nylon sieve. Weighed samples of approximately $0.5 \mathrm{~g}$ were placed in a polytetrafluoroethylene digestion tank along with $65-68 \%$ nitric acid and 30\% hydrogen peroxide for digestion of the heavy metals to make them easy to measure. An AAS Zeenit 700P atomic absorption spectrometer was used to determine the $\mathrm{Pb}$ and $\mathrm{Cd}$ contents in the aboveground and underground organs. The reagents used in the test were excellent grade, with strict quality control. 


\section{Treatment and determination of soil samples}

The soil samples were air-dried, crushed and ground with wood rods, sieved $(<0.149$ $\mathrm{mm}$ ), and stored until measurement (Hu et al., 2014; Zhu et al., 2015; Vogelmann et al., 2015) of the $\mathrm{Pb}$ and $\mathrm{Cd}$ contents by the method outlined in GB/T 17141-1997. The $\mathrm{pH}$ was measured on the basis of NY/T 1377-2007.

\section{Method for evaluation of heavy metal pollution}

The grade II soil environmental quality standard was used as the evaluation criterion of soil $\mathrm{Pb}$ and $\mathrm{Cd}$ geoccumulation indices. The geoccumulative index $\left(I_{G e o}\right)$ was used to evaluate the degree of $\mathrm{Pb}$ and $\mathrm{Cd}$ pollution. The $I_{G e o}(E q .1)$ was obtained in accordance with Muller (1969).

$$
I_{G e o}=\log _{2}\left(\frac{c_{i}}{k B_{i}}\right)
$$

In the formula, $I_{G e o}$ is the geoccumulation index, $c_{i}$ is the measured mass concentration of heavy metal I $\left(\mathrm{mg} \mathrm{kg}^{-1}\right), B_{i}$ is the environmental background level of the measured element (soil environmental quality standard grade II, in Table 1), and $k$ is a correction factor because the diagenesis may cause a change in the background value (generally $k=1.5$ ) (Wang et al., 2015). According to the $I_{G e o}$, the pollution levels of heavy metals can be classified (Table 2), the higher $I_{G e o}$ is, the more serious of the pollution.

Table 1. Descriptive statistics of the Pb and Cd concentrations $\left(\mathrm{mg} \mathrm{kg}^{-1}\right)$ in the tailings of the study area

\begin{tabular}{c|c|c|c|c|c|c}
\hline $\begin{array}{c}\text { Distance from } \\
\text { tailing slag }\end{array}$ & Elements & $\mathbf{p H}$ & $\begin{array}{c}\text { Range } \\
\left(\mathbf{m g ~ k g}^{-1}\right)\end{array}$ & $\begin{array}{c}\text { Mean } \\
\left(\mathbf{m g ~ k g} \mathbf{~ k}^{-1}\right)\end{array}$ & $\begin{array}{c}\text { Standard } \\
\mathbf{d e v i a t i o n}\end{array}$ & $\begin{array}{c}\text { Grade II of GB } \\
\mathbf{1 5 6 1 8 - 1 9 9 5}\left(\mathbf{m g ~ k g}^{-1}\right)\end{array}$ \\
\hline \multirow{2}{*}{$0 \mathrm{~m}$} & $\mathrm{Cd}$ & $7.48-7.60$ & $0.47-5.34$ & 2.64 & 2.51 & 0.6 \\
& $\mathrm{~Pb}$ & & $2506.90-3369.92$ & 2471.70 & 1117.38 & 350 \\
\hline \multirow{2}{*}{$10 \mathrm{~m}$} & $\mathrm{Cd}$ & \multirow{2}{*}{$7.53-7.90$} & $3.42-9.00$ & 5.91 & 2.84 & 0.6 \\
& $\mathrm{~Pb}$ & & $1779.29-2612.68$ & 2231.01 & 421.09 & 350 \\
\hline \multirow{2}{*}{$30 \mathrm{~m}$} & $\mathrm{Cd}$ & \multirow{2}{*}{$8.00-8.11$} & $0.17-0.39$ & 0.26 & 0.12 & 0.6 \\
& $\mathrm{~Pb}$ & & $32.12-75.61$ & 71.40 & 37.36 & 350 \\
\hline \multirow{2}{*}{$50 \mathrm{~m}$} & $\mathrm{Cd}$ & \multirow{2}{*}{$7.54-7.84$} & $0.16-0.47$ & 0.33 & 0.16 & 0.6 \\
& $\mathrm{~Pb}$ & & $28.02-175.19$ & 100.13 & 73.63 & 350 \\
\hline
\end{tabular}

Table 2. Heavy metals geoaccumulation index graduation standard

\begin{tabular}{c|c|c}
\hline $\boldsymbol{I}_{\text {Geo }}$ & Grade & Pollution level \\
$\geq 5$ & 6 & Serious \\
$4 \sim 5$ & 5 & Heavy \\
$3 \sim 4$ & 4 & Biased \\
$2 \sim 3$ & 3 & Moderate \\
$1 \sim 2$ & 2 & Mild \\
$0 \sim 1$ & 1 & Light \\
$<0$ & 0 & No pollution \\
\hline
\end{tabular}




\section{Data processing}

Plant bioaccumulation factor (BCF) was calculated by Eq.2:

$$
\boldsymbol{B C F}=\frac{c_{p}}{c_{s}}
$$

In the formula, $\mathrm{BCF}$ is the bioaccumulation factor, $C_{p}$ is the concentration of $\mathrm{Pb}$ or $\mathrm{Cd}$ in the ground or underground part of the plant $\left(\mathrm{mg} \mathrm{kg}^{-1}\right), C_{s}$ is the content of $\mathrm{Pb}$ or $\mathrm{Cd}$ in the soil $\left(\mathrm{mg} \mathrm{kg}^{-1}\right), \mathrm{BCF}$ is an important index to measure the heavy metals enrichment capacity. The larger BCF is, the higher the enrichment efficiency of the plant. The larger BCF indicates the stronger mobility of the heavy metal.

The plant transfer coefficient (TF) was calculated as Eq.3:

$$
T F=\frac{F_{i}}{R_{i}}
$$

where TF is the transfer coefficient, $F_{i}$ is the concentration of $\mathrm{Pb}$ or $\mathrm{Cd}$ in the ground part of the plant $\left(\mathrm{mg} \mathrm{kg}^{-1}\right), R_{i}$ is the content of a certain element in the underground part of the plant $\left(\mathrm{mg} \mathrm{kg}^{-1}\right)$.

\section{Results and Discussion}

\section{Evaluation of soil $\mathrm{pH}$ and $\mathrm{Pb}$ and $\mathrm{Cd}$ accumulation indices}

The $\mathrm{pH}$ values of the tailing samples and soil samples were all greater than 7.5 (Table 1). The $\mathrm{Pb}$ and $\mathrm{Cd}$ concentrations in the $0-30 \mathrm{~cm}$ soil samples are given in Table 1, along with the $\mathrm{Pb}$ and $\mathrm{Cd}$ geoccumulative pollution indices of the soil samples. The average and range of $\mathrm{Cd}$ and $\mathrm{Pb}$ concentrations in the samples taken from different distances from the tailing dumps were compared with the grade II limits (GB 15618-1995). The ratios of the average concentrations of $\mathrm{Pb}$ and $\mathrm{Cd}$ in the tailing samples to the standard limits were 7.06 and 4.40, respectively. At a distance of $10 \mathrm{~m}$ from the tailings, the samples had values of 9.85 and 6.37 . The $\mathrm{Cd}$ and $\mathrm{Pb}$ concentrations in these samples significantly exceeded the soil environmental quality standard grade II.

The average geoccumulative indices of $\mathrm{Cd}$ and $\mathrm{Pb}$ were calculated by Eq.1. The average geoccumulative indices of $\mathrm{Cd}$ and $\mathrm{Pb}$ in the tailing slag were 0.82 and 1.72 (Fig. $2)$, respectively, which corresponded to mild and moderate pollution levels, respectively. The average $\mathrm{Cd}$ and $\mathrm{Pb}$ geoccumulative indices of the soil samples taken $10 \mathrm{~m}$ from the tailing slag indicated partial to moderate pollution. The average $\mathrm{Cd}$ and $\mathrm{Pb}$ cumulative indices of the soil samples taken $30 \mathrm{~m}$ and $50 \mathrm{~m}$ from the tailing slag were negative, indicating no pollution. The results showed that there were different degrees of $\mathrm{Cd}$ and $\mathrm{Pb}$ pollution in the tailing dumps itself and within $10 \mathrm{~m}$ of the tailing pile.

\section{$P b$ and $C d$ concentrations in soil}

The mean concentrations of $\mathrm{Pb}$ and $\mathrm{Cd}$ at different soil depths are presented in Figures 3 and 4. In this section, we analyzed the $\mathrm{Pb}$ and $\mathrm{Cd}$ concentrations at depths of 0-10 cm, 10-20 cm and 20-30 cm at each sampling point. Soil taken $30-50 \mathrm{~m}$ from the tailing slag showed much lower $\mathrm{Pb}$ and $\mathrm{Cd}$ concentrations than soil $0-10 \mathrm{~m}$ from the tailing slag (Figures 3 and 4). The contents of $\mathrm{Pb}$ and $\mathrm{Cd}$ in the tailings changed greatly 
from surface to the lower layer. The average contents and the maximum values of $\mathrm{Pb}$ and $\mathrm{Cd}$ in the soil profiles of all layers were lower than the grade II soil environmental quality standards. However, the concentrations of $\mathrm{Pb}$ in the tailings in each section were higher than soil environmental quality standard (dotted lines). The content of $\mathrm{Cd}$ at $0-20$ $\mathrm{cm}$ soil depth taken $0 \mathrm{~m}$ and $30-50 \mathrm{~m}$ from the tailing slag was no pollution. The concentration of $\mathrm{Cd}$ at a depth of $20-30 \mathrm{~cm}$ was 8.9 times that of $0.6 \mathrm{mg} \mathrm{kg}^{-1}$ obtained in soil taken $10 \mathrm{~m}$ from the tailing slag. At a distance of $0 \mathrm{~m}$, the average concentrations of $\mathrm{Pb}$ and $\mathrm{Cd}$ in the 20-30 $\mathrm{cm}$ section reached 3369.9 and $5.34 \mathrm{mg} \mathrm{kg}^{-1}$, respectively. After comparison with the literature, the cause of the above phenomenon may be that $\mathrm{Pb}$ and $\mathrm{Cd}$ were present in a migratable state and a bound state in the tailings, and the precipitation and oxidation of the surface layer promoted migration from the surface layer to the lower layer, resulting in the accumulation of $\mathrm{Pb}$ and $\mathrm{Cd}$ in the lower layer $(20-30 \mathrm{~cm})$ (Adeyi and Torto, 2014).

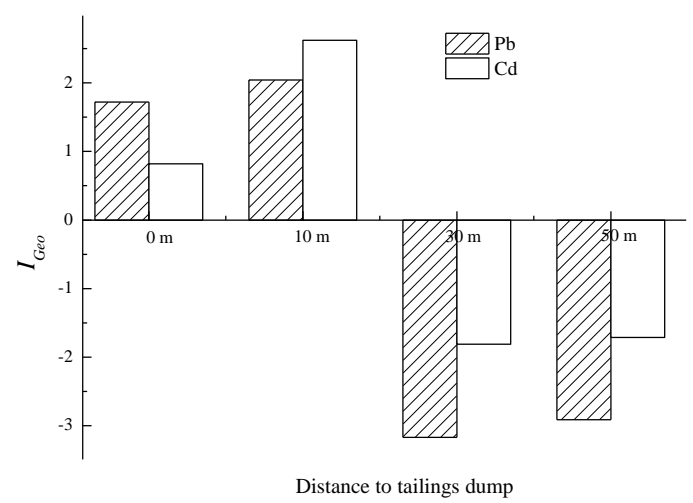

Figure 2. The average $I_{G e o}$ of $P b$ and $C d$ at different distances from the tailings dump

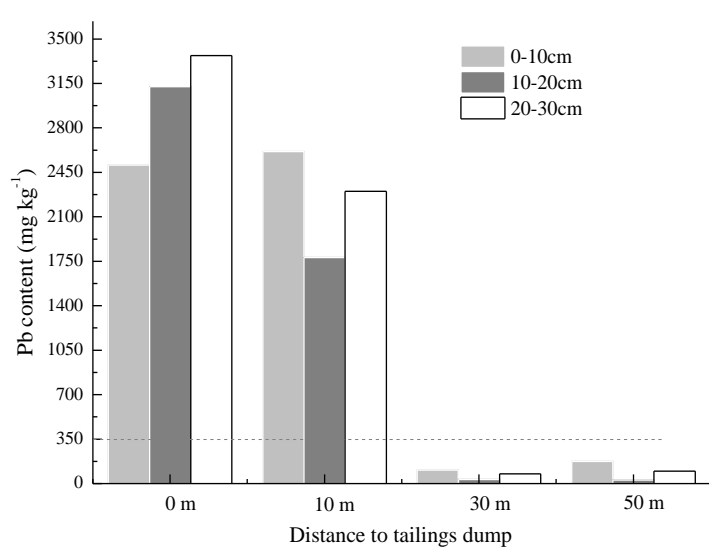

Figure 3. The average contents of $\mathrm{Pb}$ in soil profile at each sampling point

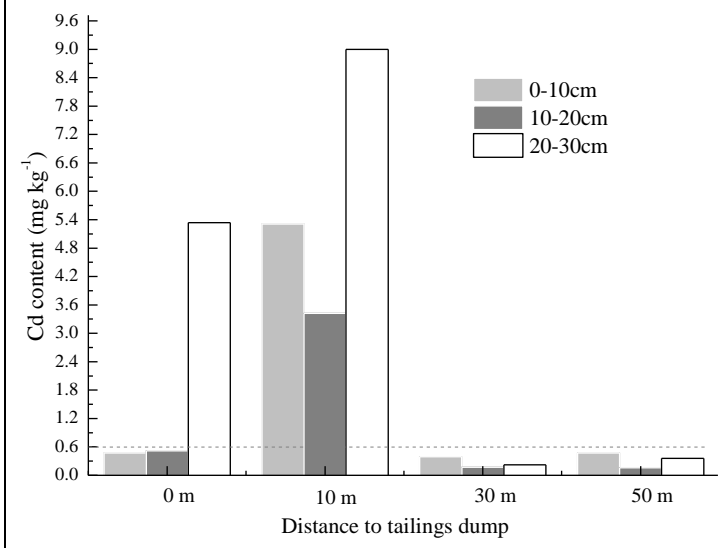

Figure 4. The average contents of $C d$ in soil profile at each sampling point

The average concentrations of $\mathrm{Pb}$ and $\mathrm{Cd}$ in the $0-10 \mathrm{~cm}$ soil were higher than those in the tailings. It is possible that the tailings accumulated for a long time, which led to the larger $\mathrm{Pb}$ and $\mathrm{Cd}$ accumulation at a depth of $20-30 \mathrm{~cm}$ at the sampling point. The main reason for the high concentrations of $\mathrm{Cd}$ and $\mathrm{Pb}$ in the $0-10 \mathrm{~cm}$ layer was that the location of the sampling point was affected by gusts of dust and particle sedimentation. 
This might also be because the tailing pile pressure accounts for a large area of land, and the accumulation time of tailings was different.

Based on the above analysis, the $\mathrm{Pb}$ and $\mathrm{Cd}$ concentrations in the study area were highest $0-10 \mathrm{~m}$ from the tailing dump, and the maximum $\mathrm{Pb}$ and $\mathrm{Cd}$ concentrations were 9.6 and 15 times higher, respectively, than those given by GB15618-1995 ( $\mathrm{pH}>7.5)$. The over-standard rates of $\mathrm{Pb}$ and $\mathrm{Cd}$ at the sampling points within an area of $0-10 \mathrm{~m}$ from the tailing dump were $100 \%$ and $83.3 \%$, respectively. In the range of $30-50 \mathrm{~m}$ from the tailing dump, the $\mathrm{Pb}$ and $\mathrm{Cd}$ contents in the soil were lower than the environmental quality standard for soils, though the background soil in Shaanxi has a $\mathrm{Pb}$ content higher than $11.5 \mathrm{mg} \mathrm{kg}^{-1}$ (Xue et al., 1986).

The results showed that there were significant differences in $\mathrm{Cd}$ content in different depths $(p=0.043<0.05)$. The $\mathrm{Cd}$ content of heavy metals did not change with the distance from the tailings slag $(p=0.161>0.05)$. There were very significant differences in $\mathrm{Pb}$ content in different depths $(p=0.000<0.01)$. The $\mathrm{Pb}$ content of heavy metals did not change with the distance from the tailings slag $(p=0.31>0.05)$.

\section{Distribution of $P b$ and $C d$ in various plant organs}

In this section, the effects of $\mathrm{Pb}$ and $\mathrm{Cd}$ enrichment and transfer to plants at a distance of $10 \mathrm{~m}$ from the tailings dump were analyzed and compared with the corresponding soil environment (Fig. 5).
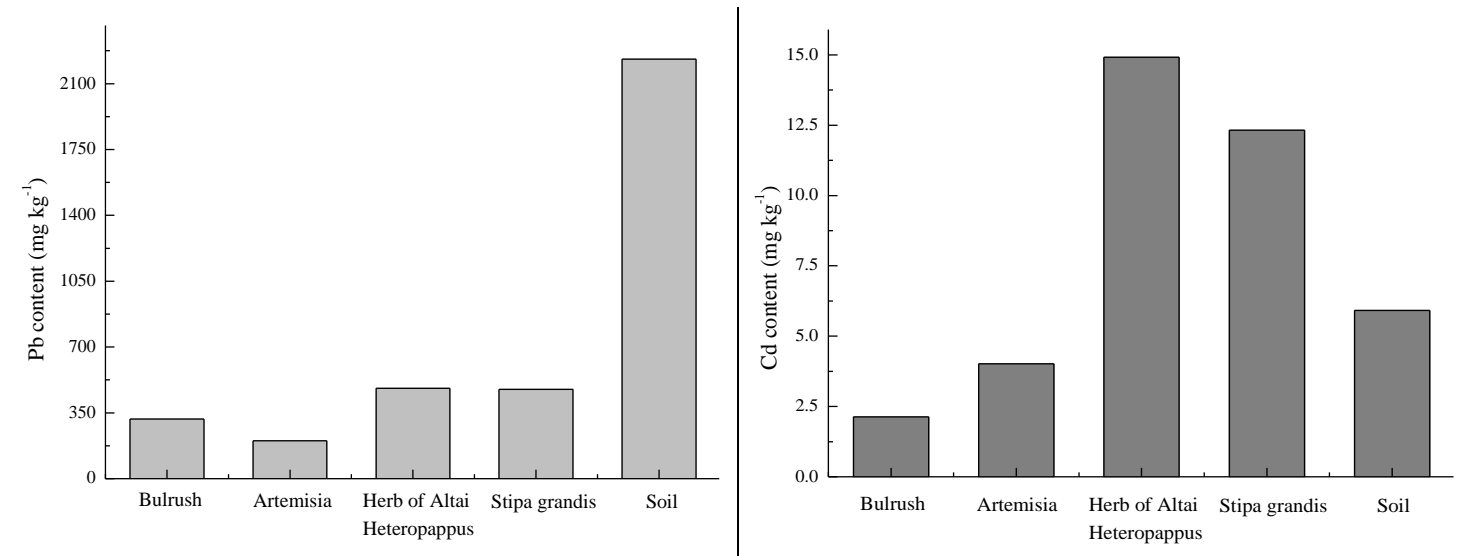

Figure 5. Comparison of $\mathrm{Pb}$ and $\mathrm{Cd}$ concentrations and soil concentrations $10 \mathrm{~m}$ from tailings slag

The bioaccumulation factor (BCF) and transfer coefficient (TF) of Bulrush (Phragmites communis (Cav.) Trin. ex Steud.) (Poales family), Capillary Wormwood (Artemisia capillaries) (Compositae family), Heteropappusaltaicus (Artemisia gmelinii) (Compositae family), Stipa (Stipa capillata Linn.) (Gramineae family) $10 \mathrm{~m}$ from tailing slag are shown in Table 3. The BCF and TF were calculated by Eq.2 and Eq.3, respectively.

From Table 3, we can see that the values of the BCF of Cd for Heteropappusaltaicus and Stipa were more than 1 and the BCF of Pb was less than 0.3. Among the four plants, the $\mathrm{BCF}$ of $\mathrm{Pb}$ was similar for Heteropappusaltaicus and Stipa, and the two plants had similar $\mathrm{Pb}$ enrichment abilities. The TFs of Capillary Wormwood, Heteropappusaltaicus and Stipa for $\mathrm{Pb}$ and $\mathrm{Cd}$ were higher than 1. 
The $\mathrm{Cd}$ and $\mathrm{Pb}$ distributions in various plant organs taken at a distance of $10 \mathrm{~m}$ from the tailing slag are shown in Table 4. At the sampling point $10 \mathrm{~m}$ from the tailing slag, the $\mathrm{Cd}$ and $\mathrm{Pb}$ concentrations in different organs of Bulrush, Heteropappusaltaicus and Stipa were compared. The results showed that the stem and leaves had higher $\mathrm{Pb}$ and $\mathrm{Cd}$ accumulation than the roots. Heteropappusaltaicus leaves had the highest $\mathrm{Pb}$ accumulation. Taking the results of Table 3 and Table 4 into consideration, Heteropappusaltaicus had better $\mathrm{Pb}$ and $\mathrm{Cd}$ accumulation ability. There might be two reasons for this. Heteropappusaltaicus, Capillary Wormwood and Stipa were the dominant crops around the tailing slag and thus had adapted to their growth environment and formed a specific tolerance mechanism. In addition, the stems and leaves of the Heteropappusaltaicus plants were covered with villus. These special physiological characteristics play a certain role in the accumulation of $\mathrm{Cd}$ and $\mathrm{Pb}$, therefore, the $\mathrm{Cd}$ and $\mathrm{Pb}$ contents in the stem and leaf were generally higher than those in the underground organs. Heteropappusaltaicus had a large coverage in the local area. Theoretically, extraction this plant could reduce the degree of $\mathrm{Cd}$ and $\mathrm{Pb}$ pollution in soil around the tailing slag.

Table 3. Plant bioaccumulation factor $(B C F)$ and transfer factor $(T F)$

\begin{tabular}{c|c|cccc|cccc}
\hline \multirow{2}{*}{$\begin{array}{c}\text { Distance } \\
\text { from } \\
\text { tailings } \\
\text { slag }\end{array}$} & \multirow{2}{*}{ Element } & \multicolumn{4}{|c|}{ BCF } & \multicolumn{4}{c}{ TF } \\
\cline { 2 - 10 } & & Bulrush & $\begin{array}{c}\text { Capillary } \\
\text { Wormwood }\end{array}$ & $\begin{array}{c}\text { Heteropa- } \\
\text { ppusaltaicus }\end{array}$ & Stipa & Bulrush & $\begin{array}{c}\text { Capillary } \\
\text { Wormwood }\end{array}$ & $\begin{array}{c}\text { Heteropa- } \\
\text { ppusaltaicus }\end{array}$ & Stipa \\
\hline \multirow{2}{*}{$10 \mathrm{~m}$} & $\mathrm{Cd}$ & 0.279 & 0.785 & 2.97 & 2.26 & 0.557 & 2.55 & 2.11 & 1.42 \\
& $\mathrm{~Pb}$ & 0.094 & 0.097 & 0.224 & 0.230 & 0.406 & 1.50 & 1.17 & 1.41 \\
\hline
\end{tabular}

Table 4. The distribution of $\mathrm{Cd}$ and $\mathrm{Pb}$ concentrations $\left(\mathrm{mg} \mathrm{kg}^{-1}\right)$ in different plant organs

\begin{tabular}{|c|c|c|c|c|c|c|c|c|}
\hline \multirow[b]{2}{*}{$\begin{array}{l}\text { Distance from } \\
\text { tailings slag }\end{array}$} & \multirow[b]{2}{*}{ Element } & \multicolumn{7}{|c|}{ Plant } \\
\hline & & $\begin{array}{l}\text { Bulrush } \\
\text { root }\end{array}$ & $\begin{array}{c}\text { Bulrush } \\
\text { stem }\end{array}$ & $\begin{array}{c}\text { Bulrush } \\
\text { leaves }\end{array}$ & $\begin{array}{c}\text { Capillary } \\
\text { Wormwood } \\
\text { root }\end{array}$ & $\begin{array}{r}\text { Cap } \\
\text { Worn } \\
\text { st } \\
\end{array}$ & $\begin{array}{l}\text { ary } \\
\text { ood } \\
\end{array}$ & $\begin{array}{c}\text { Capillary } \\
\text { Wormwood } \\
\text { leaves } \\
\end{array}$ \\
\hline \multirow{2}{*}{$10 \mathrm{~m}$} & $\mathrm{Cd}$ & 1.28 & 1.92 & 2.96 & 1.82 & & & 6.82 \\
\hline & $\mathrm{Pb}$ & 163.27 & 244.94 & 517.18 & 144.85 & & & 320.04 \\
\hline \multirow{2}{*}{$\begin{array}{c}\text { Distance } \\
\text { from tailings } \\
\text { slag }\end{array}$} & \multirow[b]{2}{*}{ Element } & \multicolumn{7}{|c|}{ Plant } \\
\hline & & \multicolumn{2}{|c|}{$\begin{array}{l}\text { Heteropap- } \\
\text { pusaltaicus } \\
\text { root }\end{array}$} & \multicolumn{2}{|c|}{$\begin{array}{l}\text { Heteropap- } \\
\text { pusaltaicus } \\
\text { stem }\end{array}$} & $\begin{array}{l}\begin{array}{l}\text { Heteropap- } \\
\text { pusaltaicus } \\
\text { leaves }\end{array} \\
\end{array}$ & Stipa root & t Stipa shoot \\
\hline \multirow{2}{*}{$10 \mathrm{~m}$} & $\mathrm{Cd}$ & \multicolumn{2}{|c|}{7.07} & 15.8 & \multicolumn{2}{|c|}{18.92} & 8.67 & 13.36 \\
\hline & $\mathrm{Pb}$ & \multicolumn{2}{|c|}{410.5} & 453. & \multicolumn{2}{|c|}{562.4} & 337.39 & 513.57 \\
\hline
\end{tabular}

One group of plants for phytoremediation lied in their excellent heavy metal accumulation capacity. Research had showed that Asteraceae species had the ability to remove heavy metal concentrations (Bolan et al., 2014). Some of them can absorb heavy metal ion in their tissues but usually have less biomass and slow growth rate. Because of the cosmopolitan distribution and local ecological adaptability (Rahman et al., 2008), Asteraceae could be used for removal the heavy metal pollutants. Nikolić and Stevović (2015) reported that family Asteraceae includes multiple species with phytoremediation potential including $T$. vulgare $(L), T$. parthenium (L.) and $T$. 
balsamita (L.) and S. transcaspicus Nevski. owes the ability to remove heavy metals. Xiao et al. (2018) observed that the coverage of Asteraceae family and herbs were most in the heavy metal pollution aera and Symphytum officinale Linn. has the ability to accumulate $\mathrm{Cd}$ and $\mathrm{Pb}$. In the research of Hesami et al. (2018), the heavy metal uptake ability of 16 plants shoot from family Asteraceae was investigated by calculating (BCF), (TF) and the phytoremediation potential were evaluated. The maximum shoot concentrations of $\mathrm{Pb}\left(162 \mathrm{mg} \mathrm{kg}^{-1}\right)$ were found in Taraxacum officinale F.H.Wigg and $\mathrm{Cd}\left(13 \mathrm{mg} \mathrm{kg}^{-1}\right)$ in Crepis sp. The maximum BCF of $\mathrm{Pb}$ and $\mathrm{Cd}$ were 0.326 and 1.787, respectively. Comparing the results with the BCF of Heteropappusaltaicus, the BCF of $\mathrm{Pb}$ and $\mathrm{Cd}$ were 0.224 and 2.97, respectively.

\section{Conclusion}

The soil $30 \mathrm{~m}$ and $50 \mathrm{~m}$ from the tailing dump was not polluted by heavy metals. Soil 0-10 $\mathrm{m}$ from the tailing slag showed different degrees of $\mathrm{Cd}$ and $\mathrm{Pb}$ contamination, whereas soil $10 \mathrm{~m}$ from the tailings slaghad moderately high $\mathrm{Cd}$ and $\mathrm{Pb}$ concentrations.

The $\mathrm{Cd}$ and $\mathrm{Pb}$ concentrations at depths of 0 to $30 \mathrm{~cm}$ were analyzed. The $\mathrm{Pb}$ and $\mathrm{Cd}$ contents in the tailings gradually increased from the surface to the lower layer. It is possible that the tailings accumulated fora long time, which led to the larger accumulation of $\mathrm{Pb}$ and $\mathrm{Cd}$ at a depth of $20-30 \mathrm{~cm}$ at the sampling point. The high $\mathrm{Pb}$ and $\mathrm{Cd}$ contents in the surface layer $(0-10 \mathrm{~cm})$ may be due to the location of the sampling point, which was affected by gusts of dust and particle sedimentation, and large area of the tailing pile. There were significant differences in $\mathrm{Cd}(p=0.043<0.05)$ and $\mathrm{Pb}(p=0.000<0.05)$ content in different depths, respectively.

Among the four tested plants, Heteropappusaltaicus showed a strong comprehensive $\mathrm{Cd}$ and $\mathrm{Pb}$ transfer ability and can be used as a phytoremediation plant for $\mathrm{Cd}$ and $\mathrm{Pb}$ soil pollution around tailings slag. Based on the existing research results, taking soil $\mathrm{Cd}$ and $\mathrm{Pb} 10 \mathrm{~m}$ away from tailings slag as an example, the soil contaminated by heavy metals is restored to a safe planting level, which will require equal dry weight plants and take at least 5 years under ideal conditions of equal enrichment efficiency. But it is worth noting that each part of the plant has a certain enrichment effect on heavy metals. If the plants are not properly treated, it may lead to the re-entry of heavy metals enriched by plants into the soil system. These heavy metals are mostly soluble and will cause severer harm. Selecting more dominant plants of family Asteraceae for phytoremediation of environmental pollutants is the final target.

Acknowledgements. Financial support were provided by the Fund Project of Shaanxi Key Laboratory of Land Consolidation (2018-JC16) and the Research Project of Shaanxi Provincial Land Engineering Construction Group in China (DJNY2019-18).

\section{REFERENCES}

[1] Adeyi, A. A., Torto, N. (2014): Profiling heavy metal distribution and contamination in soil of old power generation station in Lagos, Nigeria. - J American Journal of Science and Technology 1(1): 1-10.

[2] Arora, B., Şengör, S. S., Spycher, N. F., Steefel, C. I. (2015): A reactive transport benchmark on heavy metal cycling in lake sediments. - Computational Geosciences 19(3): 613-633. 
[3] Ashraf, M. A., Hussain, I., Rasheed, R., Iqbal, M., Riaz, M., Riaz, M., Arif, M. S. (2017): Advances in microbe-assisted reclamation of heavy metal contaminated soils over the last decade: A review. - Journal of Environmental Management 198(Part 1): 132-143.

[4] Bolan, N., Kunhikrishnan, A., Thangarajan, R., Kumpiene, J., Park, J., Makino, T., Kirkham, M. B., Scheckel, K. (2014): Remediation of heavy metal (loid) s contaminated soils-to mobilize or to immobilize? - Journal of Hazardous Materials 266: 141-166.

[5] Filippis, D. L. F. (2015): Chapter 8-Role of phytoremediation in radioactive waste treatment. - Soil Remediation and Plants: Prospects and Challenges 92(6): 207-254.

[6] Fiorentino, N., Ventorino, V., Rocco, C., Cenvinzo, V., Agrelli, D., Gioia, L., Mola, D., Adamo, P., Pepe, O., Fagnano, M. (2017): Giant reed growth and effects on soil biological fertility in assisted phytoremediation of an industrial polluted soil. - Science of the Total Environment 575: 1375-1383.

[7] Hesami, R., Salimi, A., Ghaderian, S. M. (2018): Lead, zinc, and cadmium uptake, accumulation, and phytoremediation by plants growing around Tang-e Douzan lead-zinc mine, Iran. - Environmental Science and Pollution Research 25(9): 8701-8714.

[8] Hu, M., Wu, J. Q., Peng, P. Q., Gan, G., Zhou, H., Liao, B. (2014): Assessment model of heavy metal pollution for arable soils and a case study in a mining area. - Acta Scientiae Circumstantiae 34(2): 423-430.

[9] Jing, F., Chen, X., Yang, Z., Guo, B. (2018): Heavy metals status, transport mechanisms, sources, and factors affecting their mobility in Chinese agricultural soils. Environmental earth sciences 77(3): 104.

[10] Kim, J. H., Ryu, T. H., Lee, S. S., Lee, S., Chung, B. Y. (2019): Ionizing radiation manifesting DNA damage response in plants: An overview of DNA damage signaling and repair mechanisms in plants. - Plant Science 278: 44-53.

[11] Luo, Y., Tu, C. (eds.) (2018): Twenty years of research and development on soil pollution and remediation in China. - The research and development of technology for contaminated site remediation. 10.1007/978-981-10-6029-8 (Chapter 48): 785-798.

[12] Mahar, A., Wang, P., Ali, A., Awasthi, M. K., Lahori, A. H., Wang, Q., Li, R. H., Zhang, Z. (2016): Challenges and opportunities in the phytoremediation of heavy metals contaminated soils: A review. - Ecotoxicology and environmental safety 126: 111-121.

[13] Marrugo-Negrete, J., Pinedo-Hernández, J., Díez, S. (2017): Assessment of heavy metal pollution, spatial distribution and origin in agricultural soils along the Sinú River Basin, Colombia. - Environmental research 154: 380-388.

[14] Ministry of environmental protection, Ministry of land and resources. (2014): National survey of soil pollution status of China. - China Envir. Protect. Indus. 5: 10-14.

[15] Muller, G. (1969): Index of geoaccumulation in sediments of the Rhine River. Geojournal 2(108): 108-118.

[16] Nikolić, M., Stevović, S. (2015): Family Asteraceae as a sustainable planning tool in phytoremediation and its relevance in urban areas. - Urban Forestry and Urban Greening 14(4): 782-789.

[17] Pascaud, G., Boussen, S., Soubrand, M., Joussein, E., Fondaneche, P., Abdeljaouad, S., Bril, H. (2015): Particulate transport and risk assessment of $\mathrm{Cd}, \mathrm{Pb}$ and $\mathrm{Zn}$ in a Wadi contaminated by runoff from mining wastes in a carbonated semi-arid context. - Journal of Geochemical Exploration 152: 27-36.

[18] Rahman, A. H. M. M., Alam, M. S., Khan, S. K., Ahmed, F., Islam, A. K. M. R., Rahman, M. M. (2008): Taxonomic studies on the family Asteraceae (Compositae) of the rajshahi division. - Research Journal of Agriculture and Biological Sciences 4(2): 134-140.

[19] Research cooperation group of analysis method of environmental pollution. (1987): Environmental Pollution Analysis Method. - 2 edition. Beijing: Science Press.

[20] Sankhla, M. S., Kumari, M., Nandan, M., Kumar, R., Agrawal, P. (2016): Heavy metals contamination in water and their hazardous effect on human health - a review. International Journal of Current Microbiology and Applied Sciences 5(10): 759-766. 
[21] Sarwar, N., Imran, M., Shaheen, M. R., Ishaque, W., Kamran, M. A., Matloob, A., Rehim, A., Hussain, S. (2017): Phytoremediation strategies for soils contaminated with heavy metals: Modifications and future perspectives. - Chemosphere 171: 710-721.

[22] Taj, Z. Z., Rajkumar, M. (2016): Perspectives of plant growth-promoting actinomycetes in heavy metal phytoremediation. - In: Subramaniam, G., Arumugam, S., Rajendran, V. (eds.) Plant Growth Promoting Actinobacteria. Springer, Singapore: 213-231

[23] Vogelmann, E. S., Reichert, J. M., Prevedello, J., Awe, G. O., Reinert, D. J. (2015): Soil hydrophobicity: comparative study of usual determination methods. - Ciencia Rura 45(2): 260-266.

[24] Wang, F., Huang, Y. Z., Wang, X. L., Gao, Z., Yu, F. X., Xu, F., Bao, Q. L., Hu, Y., Qiao, M., Jin, S. L. (2015): Ecological risk assessment of heavy metals in the surrounding soil of tungsten ores: Comparison of different evaluation methods. - Environmental Chemistry 34(2): 225-233.

[25] Wang, L., Ji, B., Hu, Y., Liu, R., Sun, W. (2017a): A review on in situ phytoremediation of mine tailings. - Chemosphere 184: 594-600.

[26] Wang, G., Zhang, S., Xiao, L., Zhong, Q., Li, L., Xu, G., Deng, O. P., Pu, Y. (2017b): Heavy metals in soils from a typical industrial area in Sichuan, China: spatial distribution, source identification, and ecological risk assessment. - Environmental Science and Pollution Research 24(1): 1-13.

[27] Xiao, R., Shen, F., Du, J., Li, R., Lahori, A. H., Zhang, Z. (2018): Screening of native plants from wasteland surrounding a $\mathrm{Zn}$ smelter in Feng County China, for phytoremediation. - Ecotoxicology and environmental safety 162: 178-183.

[28] Xue, C. Z., Xiao, L., Wu, Q. F., Li, D. Y., Wang, K. X., Li, H. E., Wang, R. (1986): Studies of background values of ten chemical elements in major agricultural soils in Shaanxi Province. - Acta Universities Agriculturalis Boreali-Occidentalis (Natural Science Edition) 3: 30-53.

[29] Yang, Q., Li, Z., Lu, X., Duan, Q., Huang, L., Bi, J. (2018): A review of soil heavy metal pollution from industrial and agricultural regions in China: Pollution and risk assessment. - Science of the Total Environment 642: 690-700.

[30] Zhu, D. W., Zhong, H., Zeng, Q. L., Yin, Y. (2015): Prediction of methylmercury accumulation in rice grains by chemical extraction methods. - Environmental Pollution 199: $1-9$. 